\title{
Griseaketides A-D, New Aromatic Polyketides from the Pathogenic Fungus Magnaporthe grisea
}

\author{
Yin-He Yang $1,2,+\left(\mathbb{D}\right.$, Da-Song Yang ${ }^{1,2,+} \oplus$, Hong-Mei Lei ${ }^{1}$, Cheng-Yun $\mathrm{Li}^{3}$, Guo-Hong $\mathrm{Li}^{1, *}$ \\ and Pei-Ji Zhao ${ }^{1, *(\mathbb{D})}$ \\ 1 State Key Laboratory for Conservation and Utilization of Bio-Resources in Yunnan, Yunnan University, \\ Kunming 650091, China; yyh8612@126.com (Y.-H.Y.); yangds@cpu.edu.cn (D.-S.Y.); \\ lhm401401@outlook.com (H.-M.L.) \\ 2 Institute of Entomoceutics Research, Dali University, Dali 671000, China \\ 3 State Key Laboratory for Conservation and Utilization of Bio-Resources in Yunnan, Yunnan Agricultural \\ University, Kunming 650205, China; metabolites@163.com \\ * Correspondence: ligh@ynu.edu.cn (G.-H.L.); pjzhao@ynu.edu.cn (P.-J.Z.); Tel.: +86-871-6503-2538 (G.-H.L.); \\ +86-871-6503-1092 (P.-J.Z.) \\ + These authors contributed equally to this work.
}

Received: 5 December 2019; Accepted: 21 December 2019; Published: 24 December 2019

\begin{abstract}
Magnaporthe grisea is the causal agent of rice blast disease, which is the most serious disease of cultivated rice. Aromatic polyketides are its typical metabolites and are involved in the infection process. In the search for novel lead compounds, chemical investigation of the fungus M. grisea M639 has led to the isolation of four new aromatic polyketides (salicylaldehyde skeleton bearing an unsaturated side chain), griseaketides A-D (1-4), as well as 15 known compounds (5-19). The structures of the new compounds were elucidated on the basis of extensive spectroscopic analyses, including HR-MS, 2D NMR. Compound 12 showed prominent activity that killed $94.5 \%$ of C. elegans at $400 \mathrm{ppm}$ and $66.9 \%$ at $200 \mathrm{ppm}$ over $24 \mathrm{~h}$. This is the first report describing the nematicidal activity of this type aromatic polyketide.
\end{abstract}

Keywords: Magnaporthe grisea; aromatic polyketide; rice blast disease; nematicidal activity

\section{Introduction}

Exploration of natural sources of novel bioactive compounds as drugs or lead compounds has been an emerging field over the past decades, and exciting evidence has been provided by the isolation of microbe-derived metabolites [1]. The fungal kingdom includes many species with unique and unusual biochemical pathways, which results in lots of structurally fascinating secondary metabolites with promising biological and pharmacological properties, such as penicillin, cyclosporine and statins [2].

A group of structurally and actively diverse metabolites were produced by plant pathogenic strains [3-5], which are responsible for function as essential determinants of pathogenicity or virulence. The rice blast fungus Magnaporthe grisea (imperfect stage of Pyricularia grisea Sacc.) causes a serious disease on agriculturally significant plants including rice, wheat, and barley. Each year rice blast causes losses of $10-30 \%$ of the rice harvest and therefore poses a threat to the world's most important food security crop [6]. Previous, studies have shown that aromatic polyketide phytotoxins [7], O-nitrophenol derivatives [8], and naphthalenones [9] are the typical secondary metabolites of $M$. grisea. Some secondary metabolites (such as melanin, siderophores and fumonisin) of pathogenic fungi often function as essential determinants of pathogenicity and are involved in the infection process $[10,11]$. Thus, examining their secondary metabolism leads to the discovery of novel compounds with interesting structures or modes of action that could be useful for agrochemistry or pharmacology [5]. In the work, 
chemical investigations of a strain M. grisea M639 have led to the discovery of four new aromatic polyketides griseaketides A-D (1-4), as well as 15 known compounds (5-19). Herein, we describe the isolation, structural elucidation and nematicidal activities of these compounds.

\section{Results}

Griseaketide A (1) was isolated as a pale yellow amorphous powder. Its molecular formula $\mathrm{C}_{14} \mathrm{H}_{16} \mathrm{O}_{4}$ was determined by HR-ESI-MS and ${ }^{13} \mathrm{C}$ NMR coupled with DEPT spectra, which indicated 7 degrees of unsaturation (Table 1). The ${ }^{1} \mathrm{H}$ NMR spectrum exhibited signals for one methyl resonance at $\delta_{\mathrm{H}} 1.94(3 \mathrm{H}, \mathrm{dd}, J=6.8,1.4 \mathrm{~Hz})$, three aromatic protons at $\delta_{\mathrm{H}} 6.65(1 \mathrm{H}, \mathrm{d}, J=8.7 \mathrm{~Hz}), 7.11(1 \mathrm{H}, \mathrm{t}$, $J=7.5 \mathrm{~Hz})$ and $7.12(1 \mathrm{H}, \mathrm{d}, J=7.5 \mathrm{~Hz})$, two olefinic protons at $\delta_{\mathrm{H}} 6.24(1 \mathrm{H}, \mathrm{dd}, J=15.8,1.4 \mathrm{~Hz})$ and 6.99 $(1 \mathrm{H}, \mathrm{dq}, J=15.8,6.8 \mathrm{~Hz})$ and four monooxygenated protons at $\delta_{\mathrm{H}} 3.93(1 \mathrm{H}, \mathrm{m}), 4.49(1 \mathrm{H}, \mathrm{d}, J=7.5 \mathrm{~Hz})$, $4.85(1 \mathrm{H}, \mathrm{d}, J=15.8 \mathrm{~Hz}), 4.70(1 \mathrm{H}, \mathrm{d}, J=15.8 \mathrm{~Hz})$. Sixteen carbon resonances observed in the ${ }^{13} \mathrm{C} N \mathrm{NR}$ spectrum coupled with the DEPT interpretations of 1 were attributable to one ketone $\left(\delta_{C} 199.2\right)$, one pair of disubstituted double bonds at $\delta_{\mathrm{C}} 132.2(\mathrm{~d})$ and $\delta_{\mathrm{C}} 144.6(\mathrm{~d})$, one monooxygenated 1,2,3-trisubstituted aromatic ring $\left[\delta_{\mathrm{C}} 150.8(\mathrm{~s}), 138.3(\mathrm{~s}), 121.9(\mathrm{~s}), 113.7(\mathrm{~d}), 127.7(\mathrm{~d}), 118.4(\mathrm{~d})\right]$, one primary alcohol at $\delta_{C} 64.3(\mathrm{t})$, two oxymethine groups at $\delta_{\mathrm{C}} 69.2(\mathrm{~d})$ and $75.4(\mathrm{~d})$, and one methyl group at $\delta_{\mathrm{C}} 18.4(\mathrm{q})$. On the basis of spectroscopic data analysis, compound 1 was deduced as an aromatic polyketide (Figure 1), similar to 3-(1',3'-pentadienyl)-3,4-dihydro-1H-2-benzopyran-4,8-diol [7]. A preliminary linear skeleton bearing two branches was deduced to be $-\mathrm{C}-8-\mathrm{C}-9-\mathrm{C}-10$ (-branch) $-\mathrm{C}-12-\mathrm{C}-13-\mathrm{C}-14$ (-branch) from complete interpretations of key cross-peaks in the COSY spectrum $(\mathrm{H}-8 / \mathrm{H}-9 / \mathrm{H}-10$; $\mathrm{H}-12 / \mathrm{H}-13 / \mathrm{H}-14)$ together with key cross-peaks in the HMBC spectrum (Figure 2): from H-8 to C-9 and C-10; from H-10 to C-8, C-9 and C-11; from H-14 to C-12 and C-13. The HMBC correlation of H-1/C-9 demonstrated that the formation of an extra pyran ring was through a bridge between C-1 and C-9. Typically, values of ${ }^{3} \mathrm{~J} \leq 2 \mathrm{~Hz}$ suggest cis configuration, and ${ }^{3} \mathrm{~J} \geq 5 \mathrm{~Hz}$ suggest trans configuration [12], so the trans-configuration was assigned to $\mathrm{H}-8$ and $\mathrm{H}-9$ on the basis of its larger coupling constant $(7.5 \mathrm{~Hz})$. As a result, the relative configuration of compound $\mathbf{1}$ is shown in Figure 1 and named as griseaketide A.

Table 1. ${ }^{1} \mathrm{H}$ and ${ }^{13} \mathrm{C}$ NMR Data of Compounds $\mathbf{1}$ and 2 ( $\delta$ in ppm, $J$ in $\mathrm{Hz}$ ).

\begin{tabular}{|c|c|c|c|c|c|c|}
\hline \multirow{2}{*}{ No. } & \multicolumn{3}{|c|}{1 (in $\left.\mathrm{CDCl}_{3}\right)$} & \multicolumn{3}{|c|}{$2\left(\right.$ in $\left.\mathrm{CDCl}_{3}\right)$} \\
\hline & $\delta_{\mathbf{H}}$ & $\delta_{\mathrm{C}}$ & НМВС & $\delta_{H}$ & $\delta_{\mathrm{C}}$ & НМВС \\
\hline \multirow{2}{*}{1} & $4.85, \mathrm{~d}(15.8)$ & \multirow{2}{*}{$64.3, \mathrm{t}$} & $2,3,7,9$ & 5.23, dd $(11.9,2.1)$ & \multirow{2}{*}{$71.2, \mathrm{t}$} & $2,7,8$ \\
\hline & $4.70, \mathrm{~d}(15.8)$ & & $2,3,7,9$ & $5.15, \mathrm{~d}(11.9)$ & & $2,7,8$ \\
\hline 2 & - & $121.9, \mathrm{~s}$ & - & - & $125.2, \mathrm{~s}$ & - \\
\hline 3 & - & $150.8, \mathrm{~s}$ & - & - & $150.3, \mathrm{~s}$ & - \\
\hline 4 & $6.65, \mathrm{~d}(8.7)$ & 113.7, d & 6 & $6.71, \mathrm{~d}(8.0)$ & $114.5, \mathrm{~d}$ & $2,3,6$ \\
\hline 5 & $7.11, \mathrm{t}(7.5$, overlap $)$ & 127.7, d & $3,4,7$ & $7.18, \mathrm{t}(7.7)$ & $129.4, \mathrm{~d}$ & 3,7 \\
\hline 6 & $7.12, \mathrm{~d}(7.5$, overlap $)$ & $118.4, \mathrm{~d}$ & $2,4,7$ & $6.73, \mathrm{~d}(7.5)$ & $113.9, \mathrm{~d}$ & $2,4,8$ \\
\hline 7 & - & $138.3, \mathrm{~s}$ & - & - & $142.4, \mathrm{~s}$ & - \\
\hline 8 & $4.49, \mathrm{~d}(7.5)$ & $69.2, \mathrm{~d}$ & $7,9,10$ & 5.73, brd $(6.0)$ & $84.4, \mathrm{~d}$ & 9,10 \\
\hline 9 & $3.93, \mathrm{~m}$ & $75.4, \mathrm{~d}$ & 1,11 & $6.25, \mathrm{dd}(15.1,6.8)$ & $141.8, \mathrm{~d}$ & 7,8 \\
\hline 10 & $\begin{array}{l}2.98, \mathrm{dd}(16.2,4.7) \\
3.03, \mathrm{dd}(16.2,7.1)\end{array}$ & $43.2, \mathrm{t}$ & $8,9,11$ & $6.53, \mathrm{dd}(15.1,11.0)$ & 129.0, d & $8,11,12$ \\
\hline 11 & - & $199.2, \mathrm{~s}$ & - & $7.15, \mathrm{dd}(15.7,11.0)$ & $142.4, \mathrm{~d}$ & $9,10,13$ \\
\hline 12 & $6.24, \mathrm{dd}(15.8,1.4)$ & $132.2, \mathrm{~d}$ & 11,14 & $6.21, \mathrm{~d}(15.7)$ & $131.4, \mathrm{~d}$ & 10,14 \\
\hline 13 & $6.99, \mathrm{dq}(15.8,6.8)$ & 144.6, d & 11,14 & - & $198.8, \mathrm{~s}$ & - \\
\hline 14 & $1.94, \mathrm{dd}(6.8,1.4)$ & $18.4, \mathrm{q}$ & 12,13 & $2.28, \mathrm{~s}$ & $27.3, \mathrm{q}$ & 12,13 \\
\hline
\end{tabular}




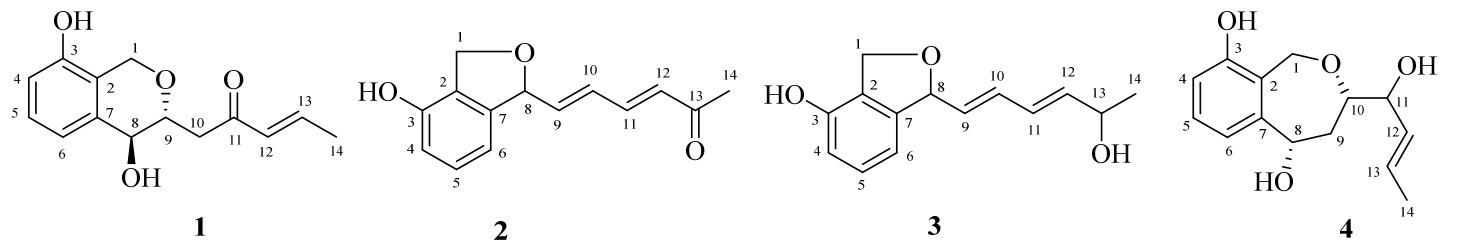<smiles>[R2]C(/C=C/C)[C@H](O)/C=C/c1cccc(O)c1C=O</smiles>

$5 \mathrm{R}=\alpha-\mathrm{OH}$ $6 \mathrm{R}=\beta-\mathrm{OH}$<smiles>C/C=C/[C@H](O)[C@@H](O)C[C@H]1OCc2c(O)cccc21</smiles>

11<smiles>CCCCC(CC)(CCCC)CCOC(=O)c1ccccc1C(=O)OCC(CC)(CC)CCCC</smiles>

17

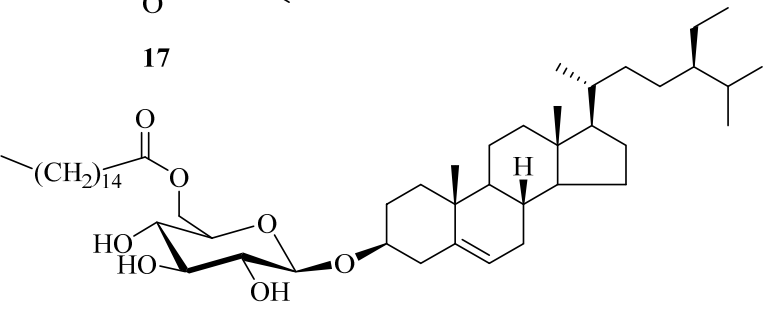

18<smiles>[R]C(C)C([R])/C=C/C=C/c1cccc(O)c1C=O</smiles>

$7 \mathrm{R}_{1}=\beta-\mathrm{OH} ; \mathrm{R}_{2}=\alpha-\mathrm{OH} ;$ $8 \mathrm{R}_{1}=\alpha-\mathrm{OH} ; \mathrm{R}_{2}=\beta-\mathrm{OH} ;$<smiles>[R]c1c(O)cccc1/C=C/[C@H](/C=C/C)CO</smiles>
$12 \mathrm{R}=\mathrm{CHO}$ $13 \mathrm{R}=\mathrm{CH}_{2} \mathrm{OH}$<smiles>[R]C(/C=C/c1cccc(O)c1CO)[C@@H](O)/C=C/C</smiles>

$9 \mathrm{R}=\beta-\mathrm{OH}$ $10 \mathrm{R}=\alpha-\mathrm{OH}$<smiles>O=C1CC[C@H](O)c2cccc(O)c2C1=O</smiles>

14

15<smiles>CCC(CC[C@H](C)C1CCC2C3C[C@H](O)[C@@]4(O)C[C@@H](OC5OCC(O)C(O)C(O)C5O)CC[C@]4(C)C3CC[C@@]21C)C(C)C</smiles>

19

Figure 1. Structures of compounds 1-19.

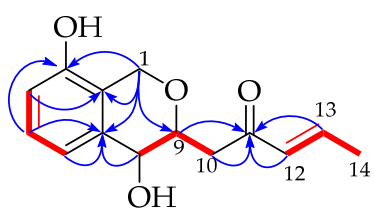

1

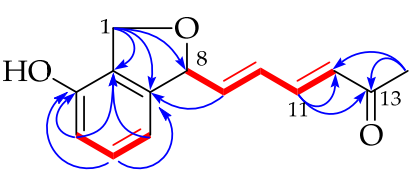

2

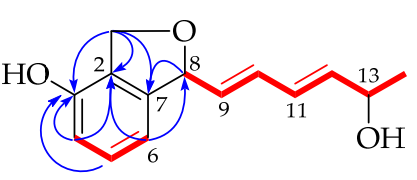

3

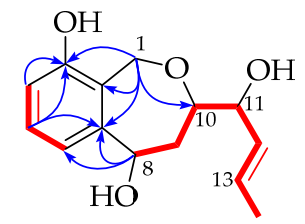

4

Figure 2. Selected HMBC $(\curvearrowright)$ and ${ }^{1} \mathrm{H}_{-}{ }^{1} \mathrm{H}$ COSY $(-)$ correlations of compounds 1-4.

Compound 2 was obtained as optically active amorphous powder $\left([\alpha]_{\mathrm{D}}^{18}-16.0 c 0.16, \mathrm{MeOH}\right)$ and its molecular formula of $\mathrm{C}_{14} \mathrm{H}_{14} \mathrm{O}_{3}$ was established by the negative HR-ESI-MS, revealing 8 degrees of unsaturation. Analysis of the ${ }^{1} \mathrm{H}$ and ${ }^{13} \mathrm{C}$ NMR (Table 1) data of 2 revealed the presence of a monooxygenated 1,2,3-trisubstituted aromatic ring, two pairs of double bonds, a primary alcohol, a carbonyl group, an oxymethine and one methyl (Figure 1). These signals revealed that 2 is similar to 1 and suggested to be an aromatic polyketide [13]. The lower-field shifting of carbon signal $\left(\delta_{\mathrm{C}-8} 84.4\right)$ in 2 and the observed HMBC correlations (Figure 2) from H-1 to C-8 suggested that C-1 and C-8 are adjacent substituents on the aromatic ring and form a 1,3-dihydroisobenzofuran system. One branch was deduced to be $-\mathrm{C}-8-\mathrm{C}-9-\mathrm{C}-10-\mathrm{C}-11-\mathrm{C}-12$ from complete interpretations of key cross-peaks in the COSY spectrum $(\mathrm{H}-8 / \mathrm{H}-9 / \mathrm{H}-10 / \mathrm{H}-11 / \mathrm{H}-12)$ together with key cross-peaks (from $\mathrm{H}-8$ to $\mathrm{C}-9$ and C-10; from H-10 to C-8, C-11 and C-12; from H-11 to C-9, C-10 and C-13; from H-14 to C-12 and C-13) in the HMBC spectrum to determinate the side chain moiety (Figure 2). The configuration of conjugated double bonds was elucidated as $E$ geometries by their coupling constants $\left(J_{9-10}=15.1 \mathrm{~Hz}\right.$, 
$J_{11-12}=15.7 \mathrm{~Hz}$ ) [14]. The configurations of C-8 cannot be determined by the present data. Thus, the structure of $\mathbf{2}$ was determined as shown in Figure 1 and named as griseaketide B.

Compound 3 was obtained as a pale yellow oil. HR-ESI-MS analysis of 3 provided a molecular formula of $\mathrm{C}_{14} \mathrm{H}_{16} \mathrm{O}_{3}$, corresponding to an unsaturation number of 6 . The $\mathrm{UV}$ absorption maxima at 226 and $271 \mathrm{~nm}$ suggested the presence of a conjugated system in the molecule. Compound 3 was very similar to compound 2 , but the ketone $\left(\delta_{C}\right.$ 198.8) of 2 was replaced by one hydroxyl in 3 (Table 2). The ${ }^{1} \mathrm{H}-{ }^{1} \mathrm{H}$ COSY spectrum of compound 3 revealed two structural fragments to be $-\mathrm{C}-8-\mathrm{C}-9-\mathrm{C}-10-\mathrm{C}-11-\mathrm{C}-12-\mathrm{C}-13-\mathrm{C}-14$ and $-\mathrm{C}-4-\mathrm{C}-5-\mathrm{C}-6-$ by the clear correlations of $\mathrm{H}-8 / \mathrm{H}-9 / \mathrm{H}-10 / \mathrm{H}-11 / \mathrm{H}-12 / \mathrm{H}-13 / \mathrm{H}-14$ and $\mathrm{H}-4 / \mathrm{H}-5 / \mathrm{H}-6$ (Figure 2). The HMBC experiment showed correlations from $\mathrm{H}-1$ to $\mathrm{C}-8$ to suggest that $\mathrm{C}-1$ and $\mathrm{C}-8$ are adjacent substituents on the aromatic ring and formed a 1,3-dihydroisobenzofuran system (Figure 2). The $E$ geometries of the two double bonds was inferred by coupling constants $\left(J_{9-10}=15.1 \mathrm{~Hz}, J_{11-12}=15.2 \mathrm{~Hz}\right)$ [14]. The configurations of C-8 and $13-\mathrm{OH}$ cannot be determined by the present data. Thus, the relative configuration of 3 is shown as Figure 1 and named as griseaketide $\mathrm{C}$.

Table 2. ${ }^{1} \mathrm{H}$ and ${ }^{13} \mathrm{C}$ NMR Data of Compounds 3 and 4 ( $\delta$ in ppm, $J$ in $\mathrm{Hz}$ ).

\begin{tabular}{|c|c|c|c|c|c|c|}
\hline \multirow{2}{*}{ No. } & \multicolumn{3}{|c|}{$3\left(\right.$ in $\left.\mathrm{CD}_{3} \mathrm{OD}\right)$} & \multicolumn{2}{|c|}{$4\left(\right.$ in $\left.\mathrm{CD}_{3} \mathrm{OD}\right)$} & \multirow[b]{2}{*}{ НМВС } \\
\hline & $\delta_{\mathbf{H}}$ & $\delta_{\mathrm{C}}$ & НМВС & $\delta_{\mathrm{H}}$ & $\delta_{\mathrm{C}}$ & \\
\hline \multirow{2}{*}{1} & 5.09, dd $(12.0,2.6)$ & \multirow{2}{*}{$71.7, \mathrm{t}$} & $2,7,8$ & $4.91, \mathrm{~d}(15.6)$ & \multirow{2}{*}{$65.8, \mathrm{t}$} & $2,3,7,10$ \\
\hline & 4.98, brd $(12.0)$ & & $2,7,8$ & $4.50, \mathrm{~d}(15.6)$ & & $2,3,7$ \\
\hline 2 & - & $126.0, \mathrm{~s}$ & - & - & 123.1, s & - \\
\hline 3 & - & $153.0, \mathrm{~s}$ & - & - & $154.0, \mathrm{~s}$ & - \\
\hline 4 & $6.67, \mathrm{~d}(7.7)$ & 115.1, d & $1,2,3,6$ & $6.68, \mathrm{~d}(7.9)$ & $114.6, \mathrm{~d}$ & 3,6 \\
\hline 5 & $7.10, \mathrm{t}(7.7)$ & $130.3, \mathrm{~d}$ & $3,4,7$ & $7.08, \mathrm{t}(7.9)$ & $128.4, \mathrm{~d}$ & $3,6,7$ \\
\hline 6 & $6.58, \mathrm{~d}(7.7)$ & $113.8, \mathrm{~d}$ & $2,4,8$ & $6.85, \mathrm{~d}(7.5)$ & $122.0, \mathrm{~d}$ & $2,4,8$ \\
\hline 7 & - & $144.1, \mathrm{~s}$ & - & - & $138.2, \mathrm{~s}$ & - \\
\hline 8 & $5.57, \mathrm{~d}(7.7)$ & $86.6, \mathrm{~d}$ & 7,9 & 4.28, brs & $67.5, \mathrm{~d}$ & $2,6,7$ \\
\hline 9 & $5.71, \mathrm{dd}(15.1,7.7)$ & $133.5, \mathrm{~d}$ & 8,11 & $2.06, \mathrm{~m} ; 1.80, \mathrm{~m}$ & $39.6, \mathrm{t}$ & $10,11,12$ \\
\hline 10 & $6.38, \mathrm{dd}(15.1,10.6)$ & $132.8, \mathrm{~d}$ & $8,11,12$ & 3.63, brt $(6.8)$ & $76.9, \mathrm{~d}$ & 8,9 \\
\hline 11 & $6.24, \mathrm{dd}(15.2,10.6)$ & $129.3, \mathrm{~d}$ & 10,13 & $4.30, \mathrm{t}(6.8)$ & $71.2, \mathrm{~d}$ & 13 \\
\hline 12 & $5.81, \mathrm{dd}(15.2,6.2)$ & $139.9, \mathrm{~d}$ & 10,13 & $5.52, \mathrm{dd}(14.6,6.8)$ & $135.3, \mathrm{~d}$ & 11,14 \\
\hline 13 & $4.29, \mathrm{dq}(6.2,6.4)$ & $68.7, \mathrm{~d}$ & 11,14 & $5.73, \mathrm{dq}(14.6,6.1)$ & $127.7, \mathrm{~d}$ & 11,14 \\
\hline 14 & $1.24, \mathrm{~d}(6.4)$ & $23.5, \mathrm{q}$ & 12,13 & $1.71, \mathrm{~d}(6.1)$ & $17.9, \mathrm{q}$ & 12,13 \\
\hline
\end{tabular}

The molecular formula of griseaketide D (4) was found to be $\mathrm{C}_{14} \mathrm{H}_{18} \mathrm{O}_{4}$ by HR-ESI-MS and ${ }^{13} \mathrm{C}$ NMR analysis. Its ${ }^{1} \mathrm{H}$ and ${ }^{13} \mathrm{C}$ NMR (Table 2) signals were similar to that of $\mathbf{1}$, except for the carbonyl group in 1 that was replaced by a hydroxyl group at $\mathrm{C}-11$. On the basis of the consecutive COSY correlations from H-8 to H-14 (Figure 2) and the coupling constants $\left(J_{12-13}=14.6 \mathrm{~Hz}\right)$, the side chain was elucidated as $1^{\prime}, 3^{\prime}, 4^{\prime}$-trihydroxy-5'E-heptaenyl. The observed HMBC (Figure 2) correlations of $\mathrm{H}-1 / \mathrm{C}-10$ suggested a seven membered ether ring was fused to the trisubstituted benzene ring through an oxygen bridge between C-1 and C-10. The relative configuration of 4 was deduced from ROESY correlations (Figure 3) and comparisons with data reported in the literature [15]. The ROESY cross-peaks of $\mathrm{H}-8 / \mathrm{H}-9 \beta$ and $\mathrm{H}-10$ indicated that they are all cofacial and assigned as $\beta$-oriented which were consistent with xylarinol B [15]. The configuration of 11-OH cannot be determined by the present data. Accordingly, the structure and relative configuration of $\mathbf{4}$ was established as shown. 


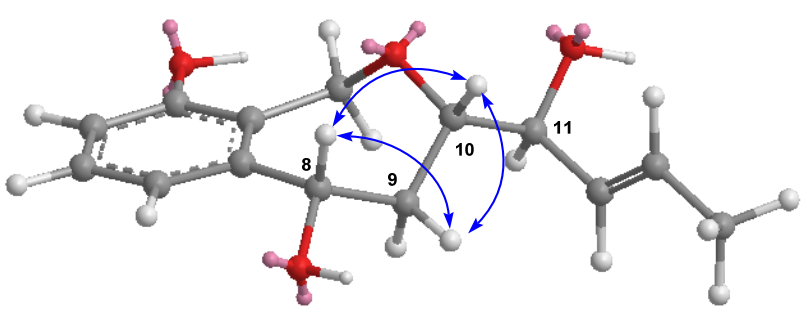

Figure 3. Key ROESY correlations of compound 4.

The known compounds were identified as $\left(1^{\prime} E, 3^{\prime} S, 4^{\prime} S, 5^{\prime} E\right)-2-\left(3^{\prime}, 4^{\prime}\right.$-dihydroxy-1', $5^{\prime}$-heptadienyl)6-hydroxybenzaldehyde (5) [16], (1'E, 3'S, $\left.4^{\prime} R, 5^{\prime} E\right)-2-\left(3^{\prime}, 4^{\prime}\right.$-dihydroxy-1',5'-heptadienyl)-6-hydroxy benzaldehyde (6) [17], ( $\left.5^{\prime} R, 6^{\prime} S\right)$-pyriculariol (7) [18], (5'S, $\left.6^{\prime} R\right)$-pyriculariol (8) [18], dihydropyriculol (9) [7], epi-dihydropyriculol (10) [7], pyriculin A (11) [19], (R)-pyricuol (12) [20], (1'E,3'R,4'E)-2hydroxymethyl-3-(3'-hydroxymethylhexa-1',4'-dienyl)phenol (13) [21], 1,3-dihydro-4-isobenzo- furanol (14) [22], 4-hydroxyphthalide (15) [23], (-)-isosclerone (16) [24], bis (2-ethylhexyl) phthalate (17) [25], daucosterol palmitate (18) [26] and $5 \alpha, 6 \beta$-dihydroxydaucosterol (19) [27] by comparison of their experimental and reported spectroscopic data.

Nematicidal activity of compounds. The pure compounds 1 and 5-12 were tested for their nematicidal activity. Compounds $\mathbf{5}-\mathbf{8}$ showed weak nematicidal activities against Caenorhabditis elegans at $400 \mathrm{ppm}$ over $48 \mathrm{~h}$, but compound 12 showed prominent activity that killed $94.5 \%$ of C. elegans at $400 \mathrm{ppm}$ and $66.9 \%$ at $200 \mathrm{ppm}$ over $24 \mathrm{~h}$.

\section{Discussion}

Rice blast, caused by infection of the rice blast fungus, Magnaporthe grisea, is the most destructive pathogen of rice worldwide. Many metabolites from rice blast fungus have been identified and they show different activities. Pyriculol caused a necrotic lesion in a rice wounding assay and showed inhibition in a spore germination bioassay [28]. Compound pyricuol inhibited shoot growth showing a stronger effect than pyriculol and dihydropyriculol $[28,29]$. In our experiment, part salicylaldehyde-type products showed nematicidal activity, and among them aldehyde group-containing compounds showed nematicidal activity, which is consistent with the literature [30], while pyricuol (12) showed a prominent nematicidal activity, which was distinguished by a different substitute on the side chain, and this further provides us with an indication of the nematicidal active compounds.

\section{Materials and Methods}

\subsection{General Experimental Procedures}

The optical rotations were measured with a Horiba SEPA-300 polarimeter (Kyoto, Japan). UV spectra were recorded on a Shimadzu UV-2401PC spectrophotometer (Kyoto, Japan). The NMR spectra were obtained with an Avance III 600 spectrometer (Bruker Biospin, Rheinstetten, Germany). The ESI and HR-ESI-MS were recorded on a Finnigan LCQ-Advantage (Thermo Finnigan, San Jose, CA, USA) and VG Auto-Spec-3000 mass spectrometer (VG, Manchester, England), respectively. Column chromatography (CC) was performed on Sephadex LH-20 (Amersham Biosciences, Piscataway, NJ, USA), silica gel (200-300 mesh, Qingdao Marine Chemical Inc., Qingdao, China), and RP-18 gel (LiChroprep, 40-63 $\mu \mathrm{m}$; Merck, Darmstadt, Germany). Semipreparative HPLC was performed on an LC3000 (Beijing Chuangxintongheng Science \& Technology Co., Ltd., Beijing, China). Fractions were monitored by TLC and visualized by heating plates sprayed with $5 \% \mathrm{H}_{2} \mathrm{SO}_{4}$ in $\mathrm{EtOH}$.

\subsection{Microbial Material}

The fungal strain of Magnaporthe grisea M639 used in this study was isolated from the leaf spot lesions of rice collected from Yunnan province, China, in August 2012. The strain has been 
preserved in the State Key Laboratory for Conservation and Utilization of Bio-Resources in Yunnan, Yunnan University.

\subsection{Cultivation, Extraction and Isolation}

The strain M. grisea M639 was cultured on PDA solid medium at $26^{\circ} \mathrm{C}$ for 7 days, and then it was inoculated into $1 \mathrm{~L}$ Erlenmeyer flasks each containing $200 \mathrm{~mL}$ of sticky rice-glucose liquid medium, which were cultivated at $26^{\circ} \mathrm{C}$ for 14 days. The obtained culture filtrates were extracted by EtOAc three times to give a crude extract $(1.32 \mathrm{~g})$. The residual $\mathrm{H}_{2} \mathrm{O}$ portion was extracted with $n$-butyl alcohol to yield a residue $(14.11 \mathrm{~g})$. The EtOAc fraction was separated by CC on RP-18 (MeOH- $\mathrm{H}_{2} \mathrm{O}, 1: 4$ to 1:0) to produce six fractions (Fr.1-Fr.6). Fr.1 was purified by Sephadex LH-20 $\left(\mathrm{CHCl}_{3}-\mathrm{MeOH}, 1: 1\right)$ and then chromatographed over a silica gel CC $\left(\mathrm{CHCl}_{3}-\mathrm{MeOH}, 100: 1\right.$ to $\left.2: 1\right)$ to yield $14(4.2 \mathrm{mg})$ and 15 (14.4 mg). Fr.2 was repeatedly subjected to silica gel CC eluting with $\mathrm{CHCl}_{3}-\mathrm{MeOH}$ (50:1 to 50:3) and then purified by Sephadex $\mathrm{LH}-20 \mathrm{CC}\left(\mathrm{CHCl}_{3}-\mathrm{MeOH}, 1: 1\right)$ to afford $\mathbf{1}(5.7 \mathrm{mg}), \mathbf{9}(3.2 \mathrm{mg}), \mathbf{1 0}(7.2 \mathrm{mg})$, $11(26.0 \mathrm{mg})$ and $16(1.2 \mathrm{mg})$. Fr.3 was subjected to Sephadex LH-20 (MeOH) and then purified by silica gel to yield $4(2.1 \mathrm{mg})$. Fr.4 was repeatedly purified by Sephadex $\mathrm{LH}-20 \mathrm{CC}\left(\mathrm{CHCl}_{3}-\mathrm{MeOH}\right.$, 1:1), semipreparative $\mathrm{RP}-18 \mathrm{CC}\left(\mathrm{MeOH}-\mathrm{H}_{2} \mathrm{O}, 1: 1\right)$ and silica gel $\mathrm{CC}\left(\mathrm{CHCl}_{3}-\mathrm{MeOH}, 50: 1\right)$ to obtain 3 (4.0 mg), $\mathbf{2}(1.8 \mathrm{mg}), \mathbf{5}(66.0 \mathrm{mg}), \mathbf{6}(6.5 \mathrm{mg}), \mathbf{7}(18.5 \mathrm{mg}), \mathbf{8}(5.7 \mathrm{mg})$ and $\mathbf{1 3}(1.1 \mathrm{mg})$. Fr.5 was subjected to Sephadex $\mathrm{LH}-20 \mathrm{CC}\left(\mathrm{CHCl}_{3}-\mathrm{MeOH}, 1: 1\right)$, followed by semipreparative $\mathrm{RP}-18 \mathrm{CC}\left(\mathrm{MeOH}-\mathrm{H}_{2} \mathrm{O}\right.$, 65:35) to yield $12(7.0 \mathrm{mg})$. Fr.6 was chromatographed over a silica gel CC (petroleum ether-EtOAc, 25:1 to 3:2) and then purified by Sephadex $\mathrm{LH}-20 \mathrm{CC}\left(\mathrm{CHCl}_{3}-\mathrm{MeOH}, 1: 1\right)$ to obtain $18(6.7 \mathrm{mg})$ and 19 $(1.8 \mathrm{mg})$. The $n$-butyl alcohol portion was chromatographed over silica gel CC $\left(\mathrm{CHCl}_{3}-\mathrm{MeOH}, 9: 1\right.$ to 0:1) and then purified by Sephadex $\mathrm{LH}-20 \mathrm{CC}\left(\mathrm{CHCl}_{3}-\mathrm{MeOH}, 1: 1\right)$ to give $17(0.7 \mathrm{mg})$.

Griseaketide A (1): Pale yellow amorphous powder; $[\alpha]_{\mathrm{D}}^{18}-29.1$ ( c 0.15, MeOH); UV (MeOH) $\lambda_{\max }$ (log ع) 202 (4.53), 220 (4.34), 274 (3.43) nm; ${ }^{1} \mathrm{H} \mathrm{NMR}\left(\mathrm{CDCl}_{3}, 600 \mathrm{MHz}\right)$ and ${ }^{13} \mathrm{C} \mathrm{NMR}\left(\mathrm{CDCl}_{3}, 150 \mathrm{MHz}\right)$ data, see Table 1; positive ESI-MS m/z $271[\mathrm{M}+\mathrm{Na}]^{+}, 287[\mathrm{M}+\mathrm{K}]^{+}, 519[2 \mathrm{M}+\mathrm{Na}]^{+}, 535[2 \mathrm{M}+\mathrm{K}]^{+}$; HR-ESI-MS m/z 247.0978 [M - H] $]^{-}$(calcd for $\mathrm{C}_{14} \mathrm{H}_{15} \mathrm{O}_{4}, 247.0976$ ).

Griseaketide B (2): Colorless amorphous powder; $[\alpha]_{\mathrm{D}}^{18}-16.0($ c $0.16, \mathrm{MeOH}) ; \mathrm{UV}(\mathrm{MeOH}) \lambda_{\max }$ $(\log \varepsilon) 202$ (4.23), $270(3.90) \mathrm{nm} ;{ }^{1} \mathrm{H}$ NMR $\left(\mathrm{CDCl}_{3}, 600 \mathrm{MHz}\right)$ and ${ }^{13} \mathrm{C} \mathrm{NMR}\left(\mathrm{CDCl}_{3}, 150 \mathrm{MHz}\right)$ data, see Table 1; negative ESI-MS m/z 229 [M - H] $]^{-}$; HR-ESI-MS m/z $229.0873[\mathrm{M}-\mathrm{H}]^{-}$(calcd for $\mathrm{C}_{14} \mathrm{H}_{13} \mathrm{O}_{3}$, 229.0870).

Griseaketide C (3): Pale yellow oil; $[\alpha]_{\mathrm{D}}^{18}+15.2(c 0.31, \mathrm{MeOH}) ; \mathrm{UV}(\mathrm{MeOH}) \lambda_{\max }(\log \varepsilon) 201$ (4.47), 226 (4.45), 271 (3.39) nm; ${ }^{1} \mathrm{H}$ NMR $\left(\mathrm{CDCl}_{3}, 600 \mathrm{MHz}\right)$ and ${ }^{13} \mathrm{C} \mathrm{NMR}\left(\mathrm{CD}_{3} \mathrm{OD}, 150 \mathrm{MHz}\right)$ data, see Table 2; negative ESI-MS $m / z 231[\mathrm{M}-\mathrm{H}]^{-}$; HR-ESI-MS $m / z 231.1027[\mathrm{M}-\mathrm{H}]^{-}$(calcd for $\mathrm{C}_{14} \mathrm{H}_{16} \mathrm{O}_{3}, 231.1027$ ).

Griseaketide D (4): Colorless amorphous powder; $[\alpha]_{\mathrm{D}}^{18}-10.6$ (c 0.31, MeOH); UV (MeOH) $\lambda_{\max }$ $(\log \varepsilon) 201$ (3.44), 215 (3.07), 271 (2.54) nm; ${ }^{1} \mathrm{H}$ NMR $\left(\mathrm{CD}_{3} \mathrm{OD}, 600 \mathrm{MHz}\right)$ and ${ }^{13} \mathrm{C} \mathrm{NMR}\left(\mathrm{CD}_{3} \mathrm{OD}\right.$, $150 \mathrm{MHz})$ data, see Table 2; positive ESI-MS $m / z 273[\mathrm{M}+\mathrm{Na}]^{+}, 523[2 \mathrm{M}+\mathrm{Na}]^{+}$. HR-ESI-MS $\mathrm{m} / \mathrm{z}$ 273.1096 [M + Na] ${ }^{+}$(calcd for $\mathrm{C}_{14} \mathrm{H}_{18} \mathrm{O}_{4}, 273.1097$ ).

\subsection{Nematicidal Activity}

The saprophytic nematode C. elegans was cultured on oatmeal medium $(20 \mathrm{~g}$ of oatmeal in $80 \mathrm{~mL}$ of $\mathrm{H}_{2} \mathrm{O}$ ) at $25^{\circ} \mathrm{C}$ for 7 days. Then the cultured nematodes were separated from the culture medium using the Baerman funnel technique, and an aqueous suspension of the nematode was prepared as a working stock. Compounds $\mathbf{1}$ and 5-12 were dissolved in methanol and then diluted to different concentrations (400 and 200 ppm) with sterile water. The nematicidal activity against $C$. elegans was assayed according to the method based on references [31,32].

Author Contributions: Investigation, Y.-H.Y., D.-S.Y. and H.-M.L.; Resources, C.-Y.L.; Writing-original draft preparation, Y.-H.Y. and D.-S.Y.; Writing-review and editing, G.-H.L., and P.-J.Z.; Supervision, G.-H.L. and P.-J.Z.; Project administration, P.-J.Z.; Funding acquisition, G.-H.L. and P.-J.Z. All authors have read and agreed to the published version of the manuscript. 
Funding: This study was financially supported by the Applied Basic Research Foundation of Yunnan Province (2018FA006) and the National Natural Science Foundation of China (31760018, 31970060 and 31860015).

Conflicts of Interest: The authors declare no conflict of interest.

\section{References}

1. Rateb, M.E.; Ebel, R. Secondary metabolites of fungi from marine habitats. Nat. Prod. Rep. 2011, 28, $290-344$. [CrossRef] [PubMed]

2. Zhong, J.J.; Xiao, J.H. Secondary metabolites from higher fungi: Discovery, bioactivity, and bioproduction. Adv. Biochem. Eng. Biotechnol. 2009, 113, 79-150. [CrossRef] [PubMed]

3. Wolpert, T.J.; Dunkle, L.D.; Ciuffetti, L.M. Host-selective toxins and avirulence determinants: What's in a name? Annu. Rev. Phytopathol. 2002, 40, 251-285. [CrossRef] [PubMed]

4. Dufour, N.; Rao, R.P. Secondary metabolites and other small molecules as intercellular pathogenic signals. FEMS Microbiol. Lett. 2011, 314, 10-17. [CrossRef] [PubMed]

5. Yang, Y.H.; Yang, D.S.; Li, G.H.; Pu, X.J.; Mo, M.H.; Zhao, P.J. Antibacterial diketopiperazines from an endophytic fungus Bionectria sp. Y1085. J. Antibiot. 2019, 72, 752-758. [CrossRef] [PubMed]

6. Talbot, N.J. On the trail of a cereal killer: Exploring the biology of Magnaporthe grisea. Annu. Rev. Microbiol. 2003, 57, 177-202. [CrossRef] [PubMed]

7. Kono, Y.; Sekido, S.; Yamaguchi, I.; Kondo, H.; Suzuki, Y.; Neto, G.C.; Sakurai, A.; Yaegashi, H. Structures of two novel pyriculol-related compounds and identification of naturally produced epipyriculol from Pyricularia oryzae. Agric. Biol. Chem. 1991, 55, 2785-2791. [CrossRef]

8. Sviridov, S.I.; Ermolinskii, B.S. Secondary metabolites of Pyricularia oryzae I. o-nitrophenol derivatives. Chem. Nat. Compd. 1990, 26, 691-696. [CrossRef]

9. Iwasaki, S.; Muro, H.; Nozoe, S.; Okuda, S.; Sato, Z. Isolation of 3,4-dihydro-3,4,8-trihydroxy-1(2H)naphthalenone and tenuazonic acid from Pyricularia oryzae cavara. Tetrahedron Lett. 1972, 13, 13-16. [CrossRef]

10. Scharf, D.H.; Heinekamp, T.; Brakhage, A.A. Human and plant fungal pathogens: The role of secondary metabolites. PLoS Pathog. 2014, 10, e1003859. [CrossRef]

11. Mobius, N.; Hertweck, C. Fungal phytotoxins as mediators of virulence. Curr. Opin. Plant Biol. 2009, 12, 390-398. [CrossRef] [PubMed]

12. Asha, K.N.; Chowdhury, R.; Hasan, C.M.; Rashid, M.A. Steroids and polyketides from Uvaria hamiltonii stem bark. Acta Pharm. 2004, 54, 57-63. [CrossRef] [PubMed]

13. Myobatake, Y.; Takemoto, K.; Kamisuki, S.; Inoue, N.; Takasaki, A.; Takeuchi, T.; Mizushina, Y.; Sugawara, F. Cytotoxic alkylated hydroquinone, phenol, and cyclohexenone derivatives from Aspergillus violaceofuscus Gasperini. J. Nat. Prod. 2014, 77, 1236-1240. [CrossRef] [PubMed]

14. Yang, D.S.; Peng, W.B.; Li, Z.L.; Wang, X.; Wei, J.G.; He, Q.X.; Yang, Y.P.; Liu, K.C.; Li, X.L. Chemical constituents from Euphorbia stracheyi and their biological activities. Fitoterapia 2014, 97, 211-218. [CrossRef] [PubMed]

15. Lee, I.K.; Jang, Y.W.; Kim, Y.S.; Yu, S.H.; Lee, K.J.; Park, S.M.; Oh, B.T.; Chae, J.C.; Yun, B.S. Xylarinols A and B, two new 2-benzoxepin derivatives from the fruiting bodies of Xylaria polymorpha. J. Antibiot. 2009, 62, 163-165. [CrossRef]

16. Leyva, A.; Blum, F.E.; Ley, S.V. A new synthesis of (-)-epipyriculol: A phytotoxic metabolite. Tetrahedron 2008, 64, 4711-4717. [CrossRef]

17. Suzuki, M.; Sugiyama, T.; Watanabe, M.; Murayama, T.; Yamashita, K. Syntheses of all four stereoisomers of pyriculol. Agric. Biol. Chem. 1987, 51, 2161-2166. [CrossRef]

18. Sasaki, A.; Tanaka, K.; Sato, Y.; Kuwahara, S.; Kiyota, H. First synthesis and absolute configuration of (-)-pyriculariol, a phytotoxin isolated from rice blast fungus, Magnaporthe grisea. Use of microwave irradiation to control Stille coupling reaction products. Tetrahedron Lett. 2009, 50, 4637-4638. [CrossRef]

19. Masi, M.; Meyer, S.; Gorecki, M.; Mandoli, A.; Di Bari, L.; Pescitelli, G.; Cimmino, A.; Cristofaro, M.; Clement, S.; Evidente, A. Pyriculins A and B, two monosubstituted hex-4-ene-2,3-diols and other phytotoxic metabolites produced by Pyricularia grisea isolated from buffelgrass (Cenchrus ciliaris). Chirality 2017, 29, 726-736. [CrossRef] 
20. Nakamura, Y.; Kiyota, H.; Ueda, R.; Kuwahara, S. Synthesis to determine the absolute configuration of (-)-pyricuol, a phytotoxin isolated from rice blast disease fungus Magnaporthe grisea. Tetrahedron Lett. 2005, 46, 7107-7109. [CrossRef]

21. Tanaka, K.; Nakamura, Y.; Sasaki, A.; Ueda, R.; Suzuki, Y.; Kuwahara, S.; Kiyota, H. Synthesis and plant growth inhibitory activity of both enantiomers of pyricuol, a phytotoxin isolated from rice blast disease fungus Magnaporthe grisea. Tetrahedron 2009, 65, 6115-6122. [CrossRef]

22. Martín-matute, B.; Nevado, C.; Cárdenas, D.J.; Echavarren, A.M. Intramolecular reactions of alkynes with furans and electron rich arenes catalyzed by $\mathrm{PtCl}_{2}$ : the role of platinum carbenes as intermediates. J. Am. Chem. Soc. 2003, 125, 5757-5766. [CrossRef] [PubMed]

23. Shimizu, N.; Kuwahara, Y. 7-Hydroxyphthalide: A new natural salicylaldehyde analog from Oulenzia sp. (Astigmata: Winterschmitiidae). Biosci. Biotechnol. Biochem. 2001, 65, 990-992. [CrossRef] [PubMed]

24. Gulder, T.A.M.; Hong, H.; Correa, J.; Egereva, E.; Wiese, J.; Imhoff, J.F.; Gross, H. Isolation, structure elucidation and total synthesis of lajollamide A from the marine fungus Asteromyces cruciatus. Mar. Drugs 2012, 10, 2912-2935. [CrossRef] [PubMed]

25. Chang, R.J.; Wang, C.H.; Zeng, Q.; Guan, B.; Zhang, W.D.; Jin, H.Z. Chemical constituents of the stems of Celastrus rugosus. Arch. Pharm. Res. 2013, 36, 1291-1301. [CrossRef]

26. Nguyen, A.T.; Malonne, H.; Duez, R.; Vanhaelen-Fastre, R.; Vanhaelen, M.; Fontaine, J. Cytotoxic constituents from Plumbago zeylanica. Fitoterapia 2004, 75, 500-504. [CrossRef] [PubMed]

27. Li, S.H.; Zhang, H.J.; Yao, P.; Niu, X.M.; Xiang, W.; Sun, H.D. Non-taxane compounds from the bark of Taxus yunnanensis. J. Asian Nat. Prod. Res. 2002, 4, 147-154. [CrossRef]

28. Kim, J.C.; Min, J.Y.; Kim, H.T.; Cho, K.Y.; Yu, S.H. Pyricuol, a new phytotoxin from Magnaporthe grisea. Biosci. Biotech. Bioch. 1998, 62, 173-174. [CrossRef]

29. Jacob, S.; Grotsch, T.; Foster, A.J.; Schuffler, A.; Rieger, P.H.; Sandjo, L.P.; Liermann, J.C.; Opatz, T.; Thines, E. Unravelling the biosynthesis of pyriculol in the rice blast fungus Magnaporthe oryzae. Microbiology 2017, 163, 541-553. [CrossRef]

30. Caboni, P.; Aissani, N.; Cabras, T.; Falqui, A.; Marotta, R.; Liori, B.; Ntalli, N.; Sarais, G.; Sasanelli, N.; Tocco, G. Potent nematicidal activity of phthalaldehyde, salicylaldehyde, and cinnamic aldehyde against Meloidogyne incognita. J. Agric. Food Chem. 2013, 61, 1794-1803. [CrossRef]

31. Sajid, M.; Azim, M.K. Characterization of the nematicidal activity of natural honey. J. Agric. Food Chem. 2012, 60, 7428-7434. [CrossRef] [PubMed]

32. Yang, Z.S.; Li, G.H.; Zhao, P.J.; Zheng, X.; Luo, S.L.; Li, L.; Niu, X.M.; Zhang, K.Q. Nematicidal activity of Trichoderma spp. and isolation of an active compound. World J. Microbiol. Biotechnol. 2010, 26, 2297-2302. [CrossRef]

Sample Availability: Samples of the compounds are available from the authors.

(C) 2019 by the authors. Licensee MDPI, Basel, Switzerland. This article is an open access article distributed under the terms and conditions of the Creative Commons Attribution (CC BY) license (http://creativecommons.org/licenses/by/4.0/). 